\title{
The interior design study of a lactation room at regional hospitals of Surakarta Indonesia from the perspective of ergonomics and regulatory standards
}

\author{
Siti Badriyaha, ${ }^{a, 1}$, I Nyoman Suyasa ${ }^{\mathrm{b}, 2}$ \\ ${ }^{a}$ Design Interior Study Program, FSRD, Institut Seni Indonesia Surakarta, Indonesia \\ ${ }^{\mathrm{b}}$ Fine Arts Study Program, FSRD, Institut Seni Indonesia Surakarta, Indonesia \\ 1 Sitibadriyah30@yahoo.com* \\ * Corresponding Author
}

Received 2020-04-10, accepted 2020-03-11, published 2021-04-16

\begin{abstract}
A lactation room is a vital facility used to support the smooth running of activities in public spaces for women, especially for nursing mothers. The lactation room is usually used by mothers to breastfeed their children privately when they are in public spaces. This study aims to determine the ergonomics and standards of lactation rooms in public facilities in Surakarta-Indonesia. This study was used to determine whether nursing mothers experience difficulties, easiness, or convenience when using these facilities. Ergonomic measurement is essential to see whether the object follows the dimensions required by the users, especially mothers and their babies. The object of this research is the lactation rooms located in several general hospitals in Surakarta. The method used is descriptive with a qualitative approach supported by quantitative data, or in other words, a dual research strategy, which is the use of multiple methods in solving a research problem. The quantitative here use numerical data, which results from field measurements, then compared with referred references, resource persons, and analyzed based on the researchers' interpretation. This research's results were in the form of lactation rooms in terms of ergonomics/anthropometry and lactation room standards. Moreover, this also serves as an input to stakeholders to provide good public facilities following ergonomic principles in lactation rooms to function optimally. These beginner research results are also expected to enrich learning sources related to Ergonomics, Interior Design, and Furniture in Interior Design Study Program ISI Surakarta.
\end{abstract}

\section{KEYWORDS}

Ergonomics

Lactation room

Hospital
This is an openaccess article under the CC-BY-SA license

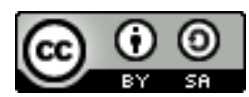

\section{Introduction}

Since the launch of Solo-Indonesia as a Kota Layak Anak (KLA) or Children-friendly City in 2015, the City Government (Pemkot) of Solo has begun building facilities that support the actualization of Solo City as a KLA (Agustinawati, Hanim, and Setiasih 2017). One of the supporting facilities as a requirement for KLA is the availability of lactation room facilities or nursing rooms in public places. Public spaces must provide lactation rooms if Solo is intended to be categorized as a children-friendly city (Bruk-Lee, Albert, and Stone 2016). This lactation room is intended for mothers who are breastfeeding to breastfeed their children in the room comfortably and safely. This is regulated in the Minister of Health Regulation number 15 of 2013, which contains Procedures for Providing Special Facilities for Breastfeeding and Expressing Breast Milk (Tamar 2020). This rule was created to support the mother's exclusive breastfeeding program for her baby. Many public places have built lactation rooms, although many other public spaces do not provide this facility. Several public places in Solo are also required to provide rooms for nursing mothers. Some public spaces that have provided lactation rooms are offices and hospitals. Therefore, the government or the public facilities where the lactation corners are available can forge partnerships with private sectors or donor institutions. Lactation corners will attract the attention of users if it is adjusted to local conditions, either socio-cultural or daily habits of the people who will use this facility (Anthony and Bernard 2018). 
Dian Sasmita, an activist from a child and women's watchdog organization in Solo, SAHABAT KAPAS, supports the government's efforts because so far, many mothers have had to use toilets or other quiet spaces to express breast milk or breastfeed their babies. "The presence of a lactation corner is needed by breastfeeding mothers, and it is perfect (Yudha Satriawan 2013). Babies and toddlers will grow up nourished. So far, there are only a few lactation rooms or breastfeeding corners. I saw that it was only at bus terminals and local public health centers. We support the presence of the lactation corner in public places," he said (Yudha Satriawan 2013). Solo has become one of the cities chosen by the State Ministry for Women's Empowerment of the Republic of Indonesia for a Children Friendly City Model Trial since 2006. The government targeted that by 2014, 100 districts/cities in Indonesia will be child-friendly areas (Setyawan and Rivanda 2019). A nursing room is a space that must be provided in every Mother and Child Hospitals. This facility is intended for mothers who gave birth and then have not been allowed to go home because the child/baby still needs medical attention (Prior 1988). The lactation rooms function to facilitate mothers to breastfeed their babies at a specific time. There are many things to be considered to make the mother and baby comfortable in this room (Schmied, Burns, and Sheehan 2019). The interaction process between baby and mother is essential. Because beyond providing breast milk, this activity is also to provide a sense of comfort and safety for the baby because even though he has to be under medical care, the baby knows that his parents are near him, which will give the baby inner satisfaction. Based on some shared past experiences and interviews with mothers who used nursing room facilities, several things felt uncomfortable (Lucas et al. 2014).

One of the crucial things that must be intensely concerned with is the baby and mother's comfort when doing the interactions. The time required for mother and baby in the room is not less than 30 minutes every 2 hours every day. From the interviews with mothers who used the room facilities, almost $100 \%$ stated that the current rooms for nursing mothers were still not as expected. The complaints often felt are sore hands and waist when breastfeeding, stuffy feeling, difficulty when changing baby clothes, poor hygiene (no place to wash hands). If these complaints are not immediately anticipated, they will interfere with the breastfeeding process. Because of the solid inner bond, if the mother feels tired, the baby will automatically get affected, so that the quality of breastfeeding is disturbed. A lactation room needs a standard size that matches the results of research in Ergonomics. Several new materials are needed to optimize the existing equipment in lactation rooms. Some vital information pointers related to babies and breastfeeding mothers health need to be implemented in these rooms so that apart from being a facility for lactation, the rooms can be used as a medium of information and education (Rivilis et al. 2008). Based on the background above, some of the problems that need solutions are: 1) the conditions of the lactation rooms at Hermina Hospital and Panti Waluya Hospital in Surakarta, in terms of regulatory aspects (Ministerial Regulations), as well as ergonomic aspects, and 2) the design of the lactation rooms at Hermina Hospital and Panti Waluya Hospital seen from the ergonomic (anthropometric) aspects of the room.

\subsection{General Hospital in Surakarta}

Surakarta as one of the municipalities in Indonesia has a number of hospitals, classified as type A, B, C and D, including General Hospitals: Moewardi, Brayat Minulyo, Kasih Ibu, Tri Harsi, Panti Waluyo, Panti Kosala, Islam Kustati, Muhammadiyah, Slamet Riyadi, Banjarsari, Dasar Mojosongo, Islam Solo, Hermina Solo. Meanwhile, in Solo, Mental Hospitals (RSJ) include RSJ Solo, RSJ Syaraf Puri Waluyo, and RSJ Dewantoro.

\subsection{Panti Waluyo General Hospital}

Panti Waluyo Hospital Surakarta was established on September 1, 1937 under the name Panti Waloejo Medical Center, on the initiative of midwives and nurses (Vroedvrouwen, Verpleegsteres \& Verpleegers Kristen, abbreviated as PVK) of Zending Hospital (Now RSUD. Dr. Moewardi Surakarta) and by the help from Mr. Soemardi and Mr. Moch. Daljono. On January 1, 1955, the hospital became the Christian Medical Association of Panti Waluyo and joined JRSK Djateng as RB. Panti Waluyo, with a capacity of 25 beds. Since 1955, RB. Panti Waluyo has become a YAKKUM work unit hospital within the YAKKUM of Surakarta branch with a capacity of 100 beds. In 1988, following government 
regulations, Panti Waluyo Hospital has been accredited as a type C hospital with a capacity of 112 beds (Fig.1), until now. It has reached 150 beds and has 16 general practitioners, 41 specialist doctors, four dentists, 157 nurses, 47 non-nurse paramedics, and 119 nonmedical staff. This hospital is located on Ahmad Yani street No.1 Surakarta.

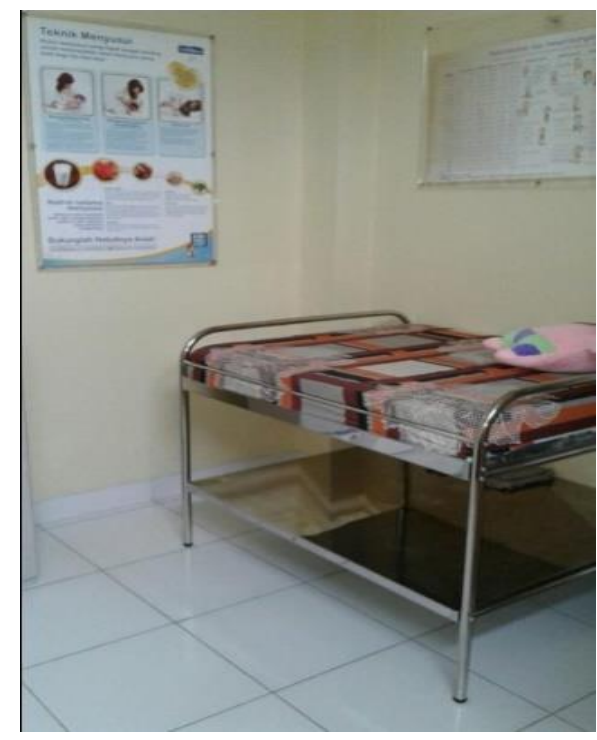

Fig. 1. Children's bed at lactation room at Panti Waluya Hospital (Photo taken by Badriyah and Suyasa 2017)

\subsection{Hermina Mother and Child Hospital}

Hermina Group Mother and Child Hospital or RSIA Hermina originated from RSIA Hermina Jatinegara, located on Jalan Raya Jatinegara Barat no. 126 East Jakarta. It was founded in 1967 and was initially named the Djatinegara Maternity Home (Rumah Bersalin/RB), with a capacity of 7 beds. RB Jatinegara was founded on the initiative of Mrs. Hermina Sulaiman. To provide ease of service to the broader community, starting in 1996, RSIA and RS Hermina began to establish branches throughout Indonesia, one of which is in Surakarta since August 2014. This hospital is located in front of DR Moewardi Hospital, precisely on Jalan Colonel Soetarto, number 16 Jebres Surakarta, and this hospital is type $\mathrm{C}$ accredited. RSIA HERMINA group is a private socio-economic hospital specializing in obstetrics and children's health services and is supported by other specialist service units. "Even though [Hermina hospital] in Solo is for health service in general, it still prioritizes mothers and children," said Diana Eleonora, a doctor who is also the hospital's marketing and public relations manager, when she was interviewed by Solopos.com (R. Wibisono 2015). As private hospitals, both Panti Waluya and Hermina hospitals also try to compete with other hospitals positively, providing the best possible facilities for consumers, the lactation room/nursing room (Fig.2). 


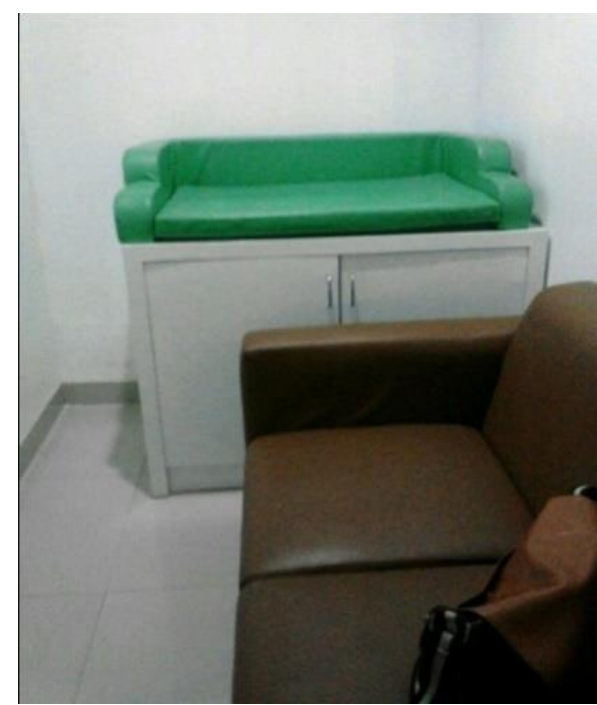

Fig. 2. Breastfeeding spot inside the lactation room at RSIA Hermina.

\subsection{Ergonomics}

Ergonomics is a science that discusses the relationship between humans and the work they do through specific work rules (Ergos; work and Nomos, natural law). Humans in their activities often need a specially designed tool or designed to make human work more accessible. With the right design, work will feel lighter, more comfortable, and faster (Pheasant 1991). Design in an ergonomic measure is a way that is applied in designing a product by taking into account the capabilities and limitations of a human's physical factors. This is done so that the designed product fits human needs (fit the job to the man) (Tilley 2001). In an ergonomic study, of course, it will not be separated from the discussion about anthropometric body measurements and the application of anthropometric data. Anthropometry, according to Kuperminc, is a set of numerical data relating to the physical characteristics of the human body, strength, and body shape and maximizing the data application in the design (Kuperminc et al. 2010). Anthropometry is a parameter of design requirements on suitability and comfort with the size of the human body, which includes: situation, frequency level and how the mechanism or operation of the equipment; body posture when on the move, as well as the requirements for the comfort of motion in the activity, consideration of tolerance in the critical dimensions of design in obtaining performance safety discussed earlier (Kolich 2003). Broadly speaking, as a science that explicitly studies the size of the human body to formulate size data for each individual or group in their activities, it is called Anthropometry (Eksioglu 2004). Differences in body size are based on age, gender, ethnicity, and types of occupation. In the spatial dimension with humans, some interactions link anthropometry and an adjustment in the size between the two. Its broad implementation is an ergonomic basis for product design planning processes and work patterns that involve human interactions (Sagot, Gouin, and Gomes 2003).

\subsection{Related research}

Some of the previous studies related to ergonomics and accessibility are; Ergonomics Study on Batik 'Solo Trans' Bus Stop in Surakarta, by R Ersnathan BP. The research object is the Batik Solo Trans bus stops alongside the Slamet Riyadi street Surakarta (Prasetyo 2016). This research aims to determine whether the bus stop facilities are following activities and needs of the people who use them. Anthropometric measurement is crucial to see whether the bus stop facilities are ergonomic. This study's results are expected to provide recommendations to the Surakarta City transportation department and other stakeholders to provide good public facilities under ergonomics. Ergonomic principles fully support the ease and convenience of the existing transportation facilities. Another study is the Ergonomics and Accessibility of Disabilities in Portable Public Toilets in Surakarta, Putri Sekar Hapsari. The object of the research is a portable public toilet located on Slamet Riyadi street Surakarta. The method used is descriptive with a qualitative approach and is supported by quantitative data, or it can be 
called a multiple research strategy. This study aims to determine the ergonomics and accessibility of people with disabilities in portable toilets in Surakarta. They know whether people with disabilities experience difficulties or even feel ease and comfort when using these facilities. The research results are expected to provide suggestions to Surakarta City Government and other stakeholders to provide good public facilities which follow the Ergonomic principles of portable public toilets to function optimally (Hapsari 2018).

\section{Method}

This study applies descriptive methods with qualitative and quantitative approaches, which in Burgess is a dual research strategy that applies various methods in problem-solving research (Burgess 1997). The system of combining the two perspectives in this study is applying qualitative results to explain research findings in the form of quantitative data. The primary data sources are public hospital facilities as the main data source, oral sources come from informants (users), and other data sources come from written documentation/literature and photos. Data were collected through the methods of observation, interviews, and questionnaires. To ensure the reliability of the data, data triangulation and method triangulation were applied. The collected data is then analyzed descriptively qualitatively using interactive analysis, which includes the following steps: data reduction, data presentation, and conclusions drawing. This study uses qualitative methods leading to interpretive analysis. This is used because the method is applicable for a small scale of research coverage but lies in a broad conceptual framework.

\subsection{Research Samples}

The samples of this research are selected using purposive sampling; the researcher selects informants as data sources based on specific positions or access, considered to have information related to the problem in-depth, and can be trusted to become data sources that are considered reliable. The object of this research is the lactation rooms at Panti Waluya Hospital and Hermina Hospital in Surakarta

\subsection{Data Sources}

Data Sources for this study include field objects, references, and informants, involving resource managers and some lactation room public facility users at the hospitals. Three methods were used to obtain the data's validity, namely: triangulation of data sources, rechecking, and peer debriefing. Data collection technique

- The observation technique is carried out through non-participant observation; whatever is done by the researcher as an observer will not affect everything that happens to the target being observed. Those targets include objects, references, and informants. Observations in this study were carried out in-depth on the size and supporting material of public facilities for lactation rooms in hospitals.

- In-depth interviews with informants. The interview process was carried out openly (open-ended) by setting the situations in an open place and open processes in an informal and unstructured manner but still focused on the research problem. The informants of this interview or the resource persons were randomly selected from the lactation room facility users.

\subsection{Analysis Technique}

The analysis technique used in this research is interactive analysis. The analysis is carried out continuously and gradually, including data reduction, data presentation, and verification or conclusion (Maxwell 2012). Components in the analysis are carried out in reciprocal interactions with the data collection process as a cycle. The researcher keeps moving between the three components of the analysis with the data collection process during the on-going data collection activities in the interactive analysis model. Then after data collection ends, the researcher moves between the three components of the analysis. Researchers researched field conditions, literature, and convenience level based on the results of interviews with resource persons. 


\subsection{Research Stages}

The first step in this process is collecting data from the existing lactation facilities for recording and documentation. The second step is observing the shape, size, and material of each of these facilities. Third, the researcher conducts interviews with resource persons who used these facilities. The fourth step is to analyze from the ergonomic aspect based on the existing literature. In the fifth stage, sub-units are combined into one integrated analysis unit. The sixth process is for further analysis and discussion to formulate a conclusion.

\section{Results and Discussion}

\subsection{The Essence and Health Requirements of Lactation Rooms}

The legal basis for the lactation room facilitation is the Minister of Health Regulation No.15 of 2013 concerning Procedures for Providing Special Facilities for Breastfeeding and Expressing (pumping out) Breastmilk; this can be described as follows in articles (9) and articles (10).

\section{- Article (9)}

Section 1: A lactation room is provided in a permanent building, which can be a separate room or as a part of a public space facility.

Section 2: A lactation room, as referred to in paragraph 1, must meet health requirements

Section 3: Every workplace and public place facility must provide breastfeeding room facilities and infrastructure following minimum standards and based on the needs.

- Article (10) The health requirements for Lactation Rooms as referred to in Article 9 paragraph

(2) at least include:

a. The availability of a particular room with a minimum size of $3 \times 4 \mathrm{~m}^{2}$ and following the number of female workers, who are breastfeeding,

b. There is a lockable door, which is easy to open and close

c. Ceramic / cement / carpet floors

d. Having adequate ventilation and air circulation

e. Free of potential hazards in the workplace, including pollution

f. The environment is considerably quiet, distant from the noise

g. The lighting in the room is sufficient and not dazzling

h. Humidity ranges from $30-50 \%$, maximum $60 \%$

i. A sink is provided with running water for washing hands and washing utensils.

In addition to articles (9) and (10), Article (11) also supported the equipment supporting lactation rooms. The equipment includes: tables, chairs with backs, breastfeeding counseling kits, media about early breastfeeding, cupboards, hot and cold dispensers, bottle washers, trash cans with lids, air conditioner/fan, nursing apron, washcloth for breast compresses, tissue/hand towel, and breastfeeding pillows. In line with the Minister of Health Regulation No.15 of 2013, the pediatric journal (2015) also reveals that the lactation room standards are as follows:

a) Safe and comfortable room,

b) Spacious room, with a minimum size of $3 \times 3 \mathrm{~m}^{2}$

c) A convenient room for breastfeeding mothers to feel calm and comfortable. This should be a cool room with good circulation. If the air temperature is hot, a fan should be there. This condition supports breastfeeding or pumping breast milk, hoping that the productivity of the amount and quality of breast milk can be optimal. 
d). A soft and comfortable chair for the mothers to lean on her back while breastfeeding

e) Sink with running water, for washing hands and bottles

f). A baby changing table or station for mothers to change diapers before or after breastfeeding.

\subsection{Observation Results:}

For the area of space that is not ideal compared to the standard of space, the facilities and infrastructure are still minimal. The standard of furniture can still be considered appropriately even though the difference is in the range of $5 \mathrm{~cm}$. In terms of lighting and ventilation, they are well accepted because the light is not dazzling.

\subsection{Observation Results:}

For the area of space close to the standard of space, the facilities and infrastructure are appropriate. The standard of furniture can still be considered at the appropriate level even though it has a $3-5 \mathrm{~cm}$ difference. In terms of lighting and ventilation, it is well accepted because the light is not dazzling, and ventilation uses AC.

\subsection{Results of the Interview Questionnaire}

- Results of Hermina Hospital Questionnaire:

1. For the level of security, $2 / 4$ of the informants noted that the lactation room is safe.

2. For the room comfort level, $3 / 4$ of the informants argued that the lactation room is not comfortable due to the less spacious and available for just limited movements.

3. For the level of cleanliness, all informants thought that the lactation room was clean.

4. For the size of the furniture, all informants stated that the furniture is quite comfortable to use.

- Results of the Panti Waluya Hospital Questionnaire:

1. For the security level, $2 / 3$ of the interviewees noted that the lactation room was reasonably safe, and one person stated that it was safe.

2. The three sources argued that the lactation room was comfortable for the room's comfort level, considering a vast space for free movement.

3. For the level of cleanliness, $2 / 3$ of the informants thought that the lactation room was clean.

4. For the size of the furniture, all informants stated that the furniture was quite comfortable to use.

\subsection{Interview Results}

- The Lactation Room at Panti Waluyo Hospital

1. Level of security and cleanliness of the lactation room at Panti Waluyo Hospital: Users stated that the nursing room's cleanliness and safety were good.

2. The level of convenience in terms of space lactation room Panti Waluyo Hospital:

3. The level of comfort of the furniture of the user R. Pojok ASI Panti Waluyo Hospital:

- The Lactation Room at Hermina Hospital

1. The comfort level of the lactation room at Hermina Hospital.

2. The comfort level of the lactation room furniture for Hermina Hospital users

3. The level of safety and cleanliness of the lactation room users at Hermina Hospital: Users stated that the nursing room's cleanliness and safety were good, but it lacked washing facilities and soap as a cleaning tool. 


\subsection{The Lactation Room Regulatory Standards at Hospitals}

The Results of Compliance with Regulatory Standards (Ministerial Regulation-No 15 of 2013 Article 10). Result of Compliance with Regulatory Standards (Ministerial Regulation- No 15 of 2013 Article 11). Result of Compliance with Regulatory Standards (Ministerial Regulation- No 15 of 2013 Article 12)

\section{Conclusion}

Based on field observation data at both hospitals, tabulation data results were obtained. The tabulation data results above show that there are still some inconsistencies from the standardization of both Julius Panero and Permenkes No.15 of 2013. According to Julius Panero's Anthropometric Standards or Permenkes (Minister of Health Regulations) No.15 of 2013, public facilities such as lactation rooms are expected to meet several requirements in the planning and placement of the space so that everyone can use them, whether for ordinary people or those who have special needs, such like following the standards of Permenkes No.15 of 2013 that there must be a sink as a hygiene and health facility - supported by the standard size of the placement following Julius Panero regarding the maximum sink height of $76.2 \mathrm{~cm}$ and meeting the standards of public facilities that are friendly to anyone, familiar people, or special needs, including signs and providing nursing equipment facilities. In this study, the object of analysis is considered to have met the standardization of lactation rooms. However, some are not following regulatory standards, only need to add facilities. However, for a space that is too narrow, perhaps it can be moved to another room that is more ideal with the standards of Permenkes No.15 of 2013 that minimum size is $300 \times 300 \mathrm{~cm}$ or a maximum of $300 \times 400 \mathrm{~cm}$ because it has less accessibility for movement space and placement of the sink as well as cupboard and other facilities. At the furniture level, it can be adjusted to the Julius Panero Anthropometric Standard.

\section{References}

Agustinawati, Eva, Diffah Hanim, and Insiwi Febriary Setiasih. 2017. "Information Technology for Children-Friendly City through Corporate Social Responbility (CSR) PT. Telkom AND XL." KnE Social Sciences, 145-52.

Anthony, Kathryn H, and Murrye Bernard. 2018. "Priming the Pump-Lactation Room Design Guidelines." Architect Magazine.

Badriyah, Siti, and I Nyoman Suyasa. 2017. "Studi Desain Interior Ruang Laktasi Rumah Sakit Umum Di Surakarta Ditinjau Dari Ergonomidan Standart Regulasi." Surakarta: ISI Surakarta.

Bruk-Lee, Valentina, Deborah Albert, and Kerri L Stone. 2016. "Lactation and the Working Woman: Understanding the Role of Organizational Factors, Lactation Support, and Legal Policy in Promoting Breastfeeding Success." In Research Perspectives on Work and the Transition to Motherhood, 217-39. Springer.

Burgess, Paul W. 1997. Theory and Methodology in Executive Function Research. Methodology of Frontal and Executive Function.

Eksioglu, Mahmut. 2004. "Relative Optimum Grip Span as a Function of Hand Anthropometry." International Journal of Industrial Ergonomics 34 (1): 1-12.

Hapsari, Putri Sekar. 2018. "Studi Ergonomi, Antrophometri Dan Aksesibilitas Difabel Pada Paturasan Umum Di Surakarta." ISI Surakarta.

Kolich, Mike. 2003. "Automobile Seat Comfort: Occupant Preferences vs. Anthropometric Accommodation." Applied Ergonomics 34 (2): 177-84.

Kuperminc, Michelle N, Matthew J Gurka, Jacey A Bennis, Marjorie G Busby, Richard I Grossberg, Richard C Henderson, and Richard D Stevenson. 2010. "Anthropometric Measures: Poor Predictors of Body Fat in Children with Moderate to Severe Cerebral Palsy." Developmental Medicine \& Child Neurology 52 (9): 824-30.

Lucas, Ruth, Rebecca Paquette, Carrie-Ellen Briere, and Jacqueline G McGrath. 2014. "Furthering Our Understanding of the Needs of Mothers Who Are Pumping Breast Milk for Infants in the NICU: An Integrative Review." Advances in Neonatal Care 14 (4): 241-52. 
Maxwell, Joseph A. 2012. Qualitative Research Design: An Interactive Approach. Vol. 41. Sage publications.

Pheasant, Stephen. 1991. Ergonomics, Work and Health. Macmillan International Higher Education.

Prasetyo, Raden Ernasthan Budi. 2016. "Studi Ergonomi Dan Standar Regulasi Pada Interior Ruang Laktasi Di Terminal Tirtonadi Surakarta Laporan Penelitian Pemula." Institut Seni Indonesia (ISI) Surakarta.

Prior, Lindsay. 1988. "The Architecture of the Hospital: A Study of Spatial Organization and Medical Knowledge." British Journal of Sociology, 86-113.

R. Wibisono. 2015. "Info Solo Kali Ini Tentang Hermina Solo, Rumah Sakit Jaringan Nasional Yang Belum Lama Ini Masuk Ke Solo." Solopos, May 2015. https://www.solopos.com/info-solo-ini-fasilitas-rs-hermina-di-solo-602414.

Rivilis, Irina, Dwayne Van Eerd, Kimberley Cullen, Donald C Cole, Emma Irvin, Jonathan Tyson, and Quenby Mahood. 2008. "Effectiveness of Participatory Ergonomic Interventions on Health Outcomes: A Systematic Review." Applied Ergonomics 39 (3): 342-58.

Sagot, Jean-Claude, Valérie Gouin, and Samuel Gomes. 2003. "Ergonomics in Product Design: Safety Factor." Safety Science 41 (2-3): 137-54.

Schmied, Virginia, Elaine Burns, and Athena Sheehan. 2019. "Place of Sanctuary: An Appreciative Inquiry Approach to Discovering How Communities Support Breastfeeding and Parenting." International Breastfeeding Journal 14 (1): $1-14$.

Setyawan, Sidiq, and Johan Rivanda. 2019. "Socialization of Child-Friendly City." Humanities \& Social Sciences Reviews 7 (3): 228-34.

Tamar, Muhammad. 2020. "Implementation of Regulation of the Minister of Health of the Republic of Indonesia Number 15 of 2013 in Improving the Performance of Female Employees at South Sulawesi Provincial Government Offices." Journal of Social and Political Sciences 3 (4).

Tilley, Alvin R. 2001. The Measure of Man and Woman: Human Factors in Design. John Wiley \& Sons.

Yudha Satriawan. 2013. "Pemkot Solo Akan Bangun Puluhan Ruang Menyusui." Voaindonesia, April 11, 2013. 